\title{
The Impact of Internal Control and Individual Morals on Fraud: An Experimental Study
}

\author{
Efrizon $^{1}$ \\ Rahmat Febrianto ${ }^{2}$ \\ Rayna Kartika ${ }^{3}$ \\ ${ }^{1,2,3}$ Faculty of Economics, Andalas University, Indonesia \\ email: efrizon.dprns@gmail.com
}

DOI: https://doi.org/10.24843/JIAB.2020.v15.i01.p11

\begin{tabular}{l}
$\begin{array}{l}\text { Jurnal Ilmiah Akuntansi } \\
\text { dan Bisnis } \\
\text { (JIAB) }\end{array}$ \\
\hline Volume 15 \\
Issue 1 \\
January 2020 \\
Page 119-126 \\
p-ISSN 2302-514X \\
e-ISSN 2303-1018 \\
\hline ARTICLE INFORMATION: \\
\hline Received: \\
11 July 2019 \\
Revised: \\
27 December 2019 \\
Accepted: \\
15 January 2020 \\
\hline
\end{tabular}

\begin{abstract}
This study aims to obtain evidence to determine whether there are differences in the likelihood to commit fraud between individuals under the conditions of present and absent internal control and between individuals with high and low levels of individual morality. The study also aims to determine whether the interaction between individual morality and internal controls lead to fraud. Results show differences among individuals under the conditions of present or absent internal control to commit fraud. Moreover, there are differences among individuals who have high and low levels of individual morality to commit fraud. Finally, results reveal that the interaction between individual morality and internal controls lead to fraud.

Keywords: Fraud, internal control, individuals moral.
\end{abstract}

\section{INTRODUCTION}

Occupational fraud is cheating one or more people from within the company itself (Peng, 2013; Timofeev, 2017). The terms occupational fraud and internal fraud are often used interchangeably (Ross, 2015). Occupational fraud is very detrimental to the company (Timofeev, 2017), reaching thousands of dollars per year (Carroll, 2015). Even ACFE (2016) mentions fraudulent actions cost the company annually at an average of 5 percent of company revenue. ACFE (2018) groups occupational fraud into three groups, namely the illegal taking of company property, corruption and fraudulent financial statements.

Fraudulent financial statements are presenting company assets or company revenues greater than they should or presenting company assets or company revenues smaller than they should (Tuanakotta, 2017). The behavior of cheating on financial statements is explained in agency theory. In agency theory, agents are more concerned with their own interests in making economic decisions. Differences in conflicts of interest results in the emergency of agency costs, namely residual loss, bonding costs and monitoring costs. Jensen \& Meckling (1976) states that monitoring costs are the burden of company owners to monitor the behavior of managers. One example of monitoring is the company's internal control system.

Hery (2016) explains that internal control is a tool for company management to ensure the achievement of company goals and objectives through the design of policies and procedures. Talet (2014) suggests that individuals are important factors in the effectiveness of internal control systems.

The influence of internal control in preventing accounting fraud has been investigated by Antarwiyati \& Purnomo (2017); Junaidi \& Ubaidillah (2018); Kusuma \& Andreina (2017); Sumbayak (2017); Thoyibatun (2009); and Wilopo (2006). Their research findings prove that effective internal control is able to prevent opportunities for financial statement fraud. 
$\mathrm{H}_{1}$ : There are differences in fraud between individuals in conditions where there is no internal control and internal control

Dewi (2016) states that in addition to factors from the company, cheating is also influenced by factors from within individuals. Mazar et al (2008b) succeeded in proving that individual behavior is influenced by morality. The results of his experiments prove that cheating individuals whose morality is low is greater than individuals whose morality is high when there is no internal control. In addition, Mazar et al (2008) also prove the internal control and morality of individuals interacting with each other.

$\mathrm{H}_{2}$ : There is a difference between cheating individuals with high mortality and individuals with low morality

Dewi (2014); Puspasari \& Suwardi (2012) found an interaction between individual morality and internal control in influencing accounting fraud. This means that if one level of moral factors or the conditions of internal control will cause individual changes in accounting fraud.

$\mathrm{H}_{3}$ : There is an interaction between internal control and individual morality

This study is a replication of the research of Mulia et al. (2017). The first reason researchers replicated the research of Mulia et al. (2017) is because there is still an empirical gap. The research of Mulia et al. (2017) prove statistically that internal control with individual morality interact with each other. The findings of this study support the results of Puspasari \& Suwardi (2012), Dewi (2016) but the research findings of S. Setiawan (2018) find that internal control with individual morality does not interact with each other. Besides that Mulia et al. (2017) found evidence of the tendency of cheating individuals with high morality and individuals with low morality are no different. The research findings of Mulia et al. (2017) is not supported by research by Dewi (2014), Puspasari \& Suwardi (2012), S. Setiawan (2018) who found statistical evidence that fraud between individuals with high morality and individuals with low morality is different.

This study has differences with the research of Mulia et al. (2017). The difference lies in the indicator of measuring the level of individual morality. The research of Mulia et al. (2017) using Christie and Geis (1970) indicators, the Mach IV Test. The Mach
IV Test indicator uses twenty question items on a scale of 1 to 5 to measure the characteristics of Machiavellian. Christie and Geis (1970) conducted 38 separate studies to assess individuals who had high Machiavelian and individuals who had low Machiavellian. Individuals who have high Machiavellian tend to cheat, often win, have a strong stance and are able to influence others compared to individuals who have low Machiavellian.

Mulia et al. (2017) classify low moral individuals if their scores are below 60 while individuals who score above 60 are included in the group of individuals with high morality. The use of Mach IV Test to measure the level of morality of individuals is not right. Astutie (1997) argues that it is very difficult to distinguish individual Machiavellian because there is no definite absolute cut-off point. Ray (1983) also states that the Mach IV test has low reliability and no construct validity.

This study uses the Defining Issue Test (DIT) as an indicator to measure the level of individual morality. The Defining Issue Test consists of six stories about dilemma cases, namely (1) Heinz and drugs that tell about Heinz's dilemma between stealing drugs for his wife who is dying or not stealing the drug; (2) runaway prisoners who tell Mrs. Jones's dilemma between reporting or not an escaped prisoner, (3) school newspapers that tell the principal's dilemma between closing or not a school newspaper, (4) doctors who tell a doctor's dilemma between injecting dead or not a patient, (5) webster who tells the dilemma of a company manager between employing or not a minority and (6) students who tell about a student's dilemma between conducting a demonstration or not about the Vietnam war (Rest et al., 1999).

Fadzly (2010: 144) states that DIT has been used as a research instrument since 1979 and its validity and reliability have been widely proven in the literature. The estimated value of Cronbach's alpha (reliability) DIT which has been used in studies for 20 years consistently reaches 0.80 (Rest et al., 1999) so that it can be concluded that DIT is more appropriate to be used in measuring the level of individual morality compared to Mach IV test.

\section{RESEARCH METHOD}

The location of the study was conducted at the Faculty of Economics, Andalas University. Padang, Indonesia. The research subjects were S1 students of the Accounting study program class of 2018 . 
Liyanarachchi (2007) stated that the use of students as surrogate practitioners was still controversial in behavioral research. Abdel-khalik (1974) tested whether MBA students could be made as an appropriate questioning as a Bank Account Officer. Abdel-khalik (1974) concluded that MBA students are poor surrogates as Bank Account Officers.

Some researchers do not fully agree with Abdelkhalik (1974). Ashton (1974) conducted an experimental study of the auditor's consideration of the strengths and weaknesses of the company's internal control. In this study, Ashton (1974) uses auditors as research subjects. Then Ashton and Kramer in 1980 replicated the research and used the University of Texas Auditing students. Ashton \& Kramer (1980) concluded that students meet the requirements to be used as auditors' surrogation. Libby et al. (2002) suggested that students are the right surrogation for research that focuses on cognitive abilities. Febrianto (2015) states that experimental research that aims to test the theory then the use of students as surrogation practitioners can be accepted. Thus, the use of students as surrogation in this study can be accepted.

Researchers used the $2 \times 2$ experimental design between subjects which meant that there were two independent variables, each of which had two levels.

Table 1. 2x2 Factorial Design Between Subject

\begin{tabular}{lcc}
\hline \multirow{2}{*}{ Individual Morality } & \multicolumn{2}{c}{ Internal control } \\
\cline { 2 - 3 } & Not Available & Available \\
\hline Low & Group 1 & Group 2 \\
High & Group 3 & Group 4 \\
\hline Source: Processed Data, 2019 & &
\end{tabular}

Researchers observed cheating behavior by the subjects by grouping them into four groups, namely group 1 is a group of individuals whose morality is low and there is no internal control, group 2 is a group of individuals whose morality is low and there is internal control, group 3 is a high morality and there is no internal control and group 4 is a group of individuals whose morality is high and there is internal control.

The Mead's Resource Equation formula that was coined by Mead in 1988 was used in this study to determine the number of research subjects needed. Febrianto (2015) states that the Mead's Resource Equation formula is widely used in experimental research using Variance Analysis (ANOVA) such as exploratory experiments, biological experiments with several factors and treatments (treatment).

$E=N-B-T$.

information:

$\mathrm{E}=\mathrm{df}$ error (preferably in the range of 10-20)

$\mathrm{N}=\mathrm{df}$ total or the total number of samples used

$\mathrm{B}=\mathrm{df}$ block

$\mathrm{T}=$ number of treatments

Each value of N, B, and T must be reduced by 1

This study had 4 treatments and zero df blocks.

With an $\mathrm{E}$ value between 10 and 20, we get the minimum $\mathrm{N}$ and $\mathrm{N}$ maximum values, so with a $2 \times 2$ factorial design, the number of research subjects per group is a minimum of 14 people and a maximum of 24 people.

$N_{\text {Minimum }}(N+1)=10-0-(4-1)=13+1=14$
$N_{\text {Maksimum }}(N+1)=20-0-(4-1)=23+1=24$

Fraud is the dependent variable in this study, that is, fraud arises due to misstatement or eliminates the amount or disclosure in the financial statements intentionally from improper actions to company assets, such as stealing company assets. Fraud is measured by calculating the difference in subject claims with the results of the answer sheet ad to 10 matrices. The subject cheats if the subject's claim is greater than the results of the answer sheet ad to 10 matrices.

Internal control and individual morality are two independent variables in this study. Researchers do environmental manipulation on internal control variables (there are no internal controls and internal controls) and individual morality variables (high moral or low moral).

The subjects in this study performed a series of procedures or manipulations that have been made by researchers. Experiments provide the whole set of procedures to subjects so that they know exactly the purpose of the experiments carried out. Each subject received 1 sheet of work paper add to 10 matrices. Each matrix contains a series of 12 different three-digit numbers (for example, 6.18) (Mazar et al., 2008b), and subjects had five minutes to find two numbers per matrix added up to 10 . In all conditions, participants received $\mathrm{Rp} 2,000.00$ for each matrix that was completed correctly. 
Under conditions of internal control, after five minutes had passed, subjects counted the number of matrices they had completed correctly. The researcher verifies the number after the participant submits the test sheet and pays based on the participant's performance.

Under conditions without internal control, after five minutes have passed, subjects were asked to count the number of matrices they had completed correctly, placing sheets of working paper into the paper shredder. They then mention the number of matrices that were completed correctly to the researchers and paid based on the reported performance without the verification process. The difference in performance between control conditions and the condition of the paper shredder measures the degree of subject fraud.

\section{RESULTS AND DISCUSSION}

Participants in this study were undergraduate students of the 2018 Accounting study program at the Faculty of Economics, Andalas University. The number of participants in this study was fifty-six people. Participants in this study aged 17 years to 19 years.

Table 2. Participant Characteristics

\begin{tabular}{llll}
\hline \multirow{2}{*}{ Condition } & \multicolumn{2}{c}{ Internal control } \\
\cline { 3 - 4 } & & Not Available & Available \\
\hline Morality & Low & 14 Person & 14 Person \\
& High & 14 Person & 14 Person \\
\hline Source: Processed Data, 2019 & \multicolumn{2}{l}{}
\end{tabular}

This study conducted several data tests including frequency distribution for descriptive statistics, homogeneity test and data normality test. Then the researcher examines the relationship between one dependent variable (metric scale) and one or more independent variables (non-metric or categorical scale with more than two categories) using analysis of variance (ANOVA).

Based on descriptive statistics it can be seen that the mean value of cheating individuals whose morality is low becomes down when there is an element of internal control compared to when there is no element of internal control. The same thing happens to individuals whose morality is high, the mean value of cheating becomes down when there is an element of internal control compared to when there is no element of control. This means that the element of internal control can reduce individual fraud both in individuals whose morality is low or individuals whose morality is high.

Researchers use Kolmogorov Smirnov to test the normality of research data because it is simpler and produces the same perception of the Kolmogorov Smirnov test results compared to using graphs. Based on the results of normality test data using Kolmogorov Smirnov obtained asymp.Sig values. (2tailed) is 0.148 (above 0.05 ) so it can be said that the data is normally distributed and meets one of the ANOVA assumptions.

Homogeneity test is a test that checks the similarity of variance in each independent variable to the dependent variable. Researchers used Levene's test of homogeneity of variance. The value of the levene test is 0.264 so each group of subjects meets the same variant.

Table 3. Test of Between-Subjects Effects

\begin{tabular}{lrlrrr}
\hline \multicolumn{1}{c}{ Source } & $\begin{array}{c}\text { Type II Sum } \\
\text { of Squares }\end{array}$ & df & $\begin{array}{c}\text { Mean } \\
\text { Square }\end{array}$ & F & Sig. \\
\hline Corrected Model & 58.339 & 3 & 19.446 & 26.863 & .000 \\
Intercept & 345.018 & 1 & 345.018 & 476.609 & .000 \\
Moralitas_Individu & 50.161 & 1 & 50.161 & 69.292 & .000 \\
Pengendalian_Internal & 5.161 & 1 & 5.161 & 7.129 & .010 \\
Moralitas_Individu * & 3.018 & 1 & 3.018 & 4.169 & .046 \\
Pengendalian_Internal & & 1 & & & \\
Error & 37.643 & 52 & 0.724 & & \\
Total & 441.000 & 56 & & & \\
Corrected Total & 95.982 & 55 & & & \\
\hline
\end{tabular}

Source: Processed Data, 2019 
The Test of Between-subjects Effects aims to compare between groups/treatments. Hypothesis 1 shows there is evidence of differences in fraud between individuals of high morality and individuals of low morality because of an F value of 69.292 and a significance of 0.000 . The results of this study support the Moral Development Theory that individuals whose morality is high always prioritize the public interest over their personal or organizational interests. The findings of this study support the research findings of Puspasari \& Suwardi (2012).

Hypothesis 2 found differences in fraud between individuals in conditions where there were elements of internal control and there were no internal controls because the $F$ value was 7.129 and the significance was 0.010 . The Effect of Internal Control on fraud itself without taking into account Individual Morality is 5.38 percent. The findings of this study support previous research by Puspasari \& Suwardi (2012) namely that effective corporate internal control will reduce the level of fraud that occurs in the company. Therefore internal control must be applied in the company

Hypothesis 3 The results of the experiment show that there is a significant interaction between individual morality and internal control because the $F$ value is 4.169 and the significance is 0.046 . The findings of this study support previous research by Dewi (2014) that internal control depends on individual morality. Individuals with low morality do not mind whether there is internal control in committing fraud. Individuals with high morality when confronted under conditions of internal control, cheating committed tends to be lower than conditions where there is no internal control.

\section{CONCLUSION}

This study aims to compare individual fraud when there are elements of internal control and there is no element of internal control between individuals of high morality and individuals of low morality. Participants in this study amounted to 56 undergraduate students of the Andalas University Accounting study program class of 2018. This study used the Two Way ANOVA test to test hypotheses.

Based on the results of the study, this study concludes that there are differences in fraud between individuals of high morality and individuals of low morality. Also, there are also differences in fraud between individuals in conditions where there is an internal control or no internal control. The results also indicate that there is an interaction between individual morality and internal control.

Based on the results of research that has been done, researchers found there are some obstacles, so this research can still be developed and improved in subsequent studies. As for some of the limitations in this study, this study only uses two independent variables, namely Internal Control and Individual Morality, even though there are still other factors that influence Fraud such as Compensation Suitability, Rule Obedience. Second, Researchers only use a 2 $\mathrm{x} 2$ experimental design so different results might be obtained if the experimental design is also different. Third, It is possible that the research subjects committed accidental cheating or human errors such as mistyped. Fourth, the results of this study cannot generalize the behavior of accounting students because at different places and times the results may be different.

Based on the conclusions of the study and the limitations faced, the researchers gave several suggestions that could be considered, Companies must conduct periodic evaluations of the ongoing Internal Control within the company and improve employee morality by internalizing the values of character and good organizational culture so that employees can work honestly and avoid cheating.

Future studies are expected to be able to use other independent variables such as Compensation Suitability, Obedience of Rules that influence individuals to commit fraud. In addition, researchers can then use variables related to participant demographics such as gender, recent education, position in the company, age, work experience

\section{REFERENCES}

Abdel-khalik, A. R. (1974). On the Efficiency of Subject Surrogation in Accounting Research. The Accounting Review, 49(4), 743-750.

Adi, M. R. K., Ardiyani, K., \& Ardianingsih, A. (2016). Analisis Faktor-Faktor Penentu Kecurangan Fraud Pada Sektor Pemerintahan (Studi Kasus Pada Dinas Pendapatan Pengelolaan Keuangan Dan Aset Daerah Kota Pekalongan). Jurnal Litbang Kota Pekalongan, 10, 1-10.

Ahriati, D., Basuki, P., \& Widiastuty, E. (2015). Analisis Pengaruh Sistem Pengendalian Internal, Asimetri Informasi, Perilaku Tidak Etis Dan Kesesuaian Kompensasi Terhadap 
Kecenderungan Kecurangan Akuntansi Pada Pemerintah Daerah Kabupaten Lombok Timur. InFestasi, 11(1), 41-55.

Aleixo, P. A. (1992). Personality And Moral Reasoning In Young Offenders. Universitas Leicester.

Alou, S. D., Ilat, V., \& Gamaliel, H. (2017). Pengaruh Kesesuaian Kompensasi, Moralitas Manajemen, Dan Keefektifan Pengendalian Internal Terhadap Kecenderungan Kecurangan Akuntansi Pada Perusahaan Konstruksi Di Manado. Jurnal Riset Akuntansi Going Concern, 12(1), 139-148.

Antarwiyati, P., \& Purnomo, R. E. (2017). Motivasi Melakukan Fraud Dan Faktor-faktor Yang Mempengaruhinya. Jurnal Akuntansi \& Auditing Indonesia, 21(7), 157-166.

Ashton, R. H. (1974). An Experimental Study of Internal Control Judgments. Journal of Accounting Research, 143-157.

Ashton, R. H., \& Kramer, S. S. (1980). Students as Surrogates in Behavioral Accounting Research/ : Some Evidence. Journal of Accounting Research, 18(1), 1-15.

Association of Certified Fraud Examiner. (2016). Survai Fraud Indonesia. Indonesia.

Association of Certified Fraud Examiner. (2018). Report To The Nations 2018 Global Study On Occupational Fraud And Abuse.

Astutie, Y. P. (1997). Karakteristik Machiavellian Dalam Profesi Akuntan, 1-9.

Asyik, N. F. (2000). Perspektif Agency Theory: Pengaruh Informasi Asimetri Terhadap Manajemen Laba (Menggunakan Pendekatan Agency Framework). Ekuitas, 4(1), 29-42.

Carroll, E. L. (2015). Occupational Fraud/: A Survey. Universitas Misissippi.

Dewi, G. A. K. R. S. (2014). Pengaruh Moralitas Individu Dan Pengendalian Internal Pada Kecurangan Akuntansi (Studi Eksperimen pada Pemerintah Daerah Provinsi Bali. Universitas Udayana.

Dewi, G. A. K. R. S. (2016). PENGENDALIAN INTERNAL PADA KECURANGAN AKUNTANSI ( Studi Eksperimen pada Pemerintah Daerah Provinsi Bali ). Jurnal Ilmiah Akuntansi, 1(1), 77-92.

Eliza, Y. (2015). Pengaruh Moralitas Individu dan Pengendalian Internal terhadap Kecenderungan Kecurangan Akuntansi (Studi Empiris Pada
SKPD di Kota Padang). Jurnal Akuntansi, 4(1), 86-100.

Fadzly, M. N. (2010). Values and Moral Development of Undergraduate Accounting Students at an Islamic University and Nonreligious University in Malaysia. Universitas Glasgow.

Febrianto, R. (2015). Pengaruh Rotasi dan Retensi Wajib Terhadap Bias Pertimbangan Auditor/ : Sebuah Penelitian Eksperimental.

Hall, J. A. (2011). Information Technology Auditing (Edisi Keti). Cengage Learning.

Hery. (2016). Auditing dan Asurans. Jakarta, Indonesia: PT Grasindo.

Indriastuti, D. E., Agusdin, \& Animah. (2016). Analisis Pengaruh Asimetri Informasi, Pengendalian Internal, Persepsi Kesesuaian Kompensasi, Moralitas Individu, Dan Ketaatan Aturan Akuntansi Terhadap Kecurangan Akuntansi. Jurnal InFestasi, 12(2), 115-130.

Jensen, M. C., \& Meckling, W. H. (1976). Theory Of The Firm: Managerial Behavior, Agency Costs And Ownership Structure. Journal Of Financial Economics 1, 3, 305-360.

Junaidi, \& Ubaidillah, M. (2018). The Influence Of Compensation Suitability And Internal Control System To Fraud With Morality As Moderating Variable. Jurnal Akuntansi Berkelanjutan Indonesia, 1(2), 214-225.

Korompis, S. N., Saerang, D. P. E., \& Morasa, J. (2018). Pengaruh Moralitas Individu, Asimetri Informasi , dan Keefektifan Pengendalian Internal Terhadap Kecenderungan Kecurangan ( Fraud ) Berdasarkan Persepsi Pada Badan Pengelola Keuangan dan Barang Milik Daerah Provinsi Sulawesi Utara. Jurnal Riset Akuntansi dan Auditing "Goodwill," 9(1), 29-36.

Kusuma, H., \& Andreina, R. R. T. R. (2017). Determinants of Accounting Frauds: Perceptions Of Indonesian Civil Servants. Research In Business \& Social Science, 6(4), $11-21$.

Lahaya, I. A. (2017). Pengaruh Moralitas Individu Dan Pengendalian Internal Terhadap Kecenderungan Kecurangan Akuntansi (Studi Eksperimen Pada Mahasiswa Jurusan Akuntansi Fakultas Ekonomi Universitas Mulawarman Samarindi. Jurnal Ekonomika Fekon UWGM Samarinda, (1994), 20-45. 
Leary, M. R. (2001). Introduction to Behavioral Research Methods (3rd ed.). Amerika Serikat: A Pearson Education Company.

Libby, R., Bloomfield, R., \& Nelson, M. W. (2002). Experimental Research in Financial Accounting. Accounting, Organizations and Society, 27, 775-810.

Liyanarachchi, G. A. (2007). Feasibility of Using Student Subjects in Accounting Experiments: a Review. Pacific Accounting Review, 19(1), 47-67. https://doi.org/10.1108/01140580710754 647

Liyanarachchi, G., \& Newdick, C. (2009). The Impact of Moral Reasoning and Retaliation on Whistle-Blowing/ : New Zealand Evidence, 24, 37-38. https://doi.org/10.1007/s10551-008$9983 \mathrm{x}$

MacMahon, J. (2000). The Effects of Cognitive Moral Development and Reinforcement Contingencies on Ethical Decision Making. Institut Politeknik Virginia.

Mazar, N., Amir, O., \& Ariely, D. (2008a). More Ways to Cheat - Expanding the Scope of Dishonesty. Journal of Marketing Research, 45(6), 1-13.

Mazar, N., Amir, O. N., \& Ariely, D. A. N. (2008b). The Dishonesty of Honest People/ : A Theory of Self-Concept Maintenance, XLV(December), 633-644.

Mazar, N., \& Ariely, D. (2006). Dishonesty In Everyday Life And Its Policy Implications. American Marketing Asociation, 25(1), 117126.

Merawati, L. K., \& Mahaputra, I. N. K. (2017). Moralitas, Pengendalian Internal Dan Gender Dalam Kecenderungan Terjadinya Fraud. Jurnal Akuntansi, 21(01), 35-46.

Mulia, M. H. K., Febrianto, R., \& Kartika, R. (2017). Pengaruh Moralitas Individu dan Pengendalian Internal terhadap Kecurangan/ : Sebuah Studi Eksperimental, 18(2), 198-208. https://doi.org/ 10.18196/jai.180283

Peng, L. (2013). The Importance of Fraud Detection Techniques From the Enron Case and The T.J Maxx Data Breach. Universitas James Madison.

Puspasari, N., \& Suwardi, E. (2012). Pengaruh Moralitas Individu Dan Pengendalian Internal Terhadap Kecenderungan Kecurangan Akuntansi: Studi Eksperimen Pada Konteks Pemerintahan Daerah, 1-30.
Ramamoorti, S. (2008). The Psychology and Sociology of Fraud/ : Integrating the Behavioral Sciences. Issues In Accounting Education, 23(4), 521-533.

Ray, J. J. (1983). Defective Validity Of The Machiavellianism Scale. The Journal of Social Psychology, 291-292. https://doi.org/10.1080/ 00224545.1983.9922836

Rest, J. R., Narvaez, D., Thoma, S. J., \& Bebeau, M. (1999). DIT2/ : Devising and Testing a Revised Instrument of Moral Judgment. Journal of Educational Psychology, 91(4), 644-659.

Ross, N. (2015). Fraud And Its Relation To The Hospitality Industry. Universitas Mississippi.

Sekaran, U. (2003). Research Methods For Business (Edisi Keem). John Wiley \& Sons, Inc.

Sekaran, U., \& Bougie, R. (2016). Research Methods For Business: A Skill-Building Approach (Edisi Ketu). Chichester, Inggris: John Wiley \& Sons, Inc.

Setiawan, M. A., \& Helmayunita, N. (2017). Pengaruh Pengendalian Internal, Tekanan Finansial, Dan Moralitas Individu Terhadap Kecenderungan Kecurangan Akuntansi: Studi Eksperimen Pada Konteks Pemerintah Daerah. ECONOMAC, 1(1), 52-67.

Setiawan, S. (2018). The Effect Of Internal Control And Individual Morality On The Tendency Of Accounting Fraud. Asia Pasific Fraud Journal, 3(1), 33-41. https://doi.org/10.21532/ apfj.001.18.03.01.04

Sholehah, N. L. H., Rahim, S., \& Muslim. (2018). Pengaruh Pengendalian Internal, Moralitas Individu dan Personal Culture Terhadap Kecurangan Akuntansi (Studi Empiris Pada OPD Provinsi Gorontalo). ATESTASI Jurnal Ilmiah Akuntansi, 1(1), 40-54.

Subagio. (2016). Identify Main Factors That Influence Corruption And Suggest How To Eradicate The Corruption Problem In Indonesia. Asia Pasific Fraud Journal, 1(1), 37-48. https://doi.org/ 10.21532/apfj.001.16.01.01.03

Sumbayak, J. S. (2017). Pengaruh Keadilan Organisasi, Sistem Pengendalian Intern, Komitmen Organisasi Dan Gaya Kepemimpinan Terhadap Kecurangan (Fraud). JOM FEKON, 4(1), 3168-3182.

Talet, M. Z. N. (2014). AnAnalysis Of The Determinants Of Internal Control Disclosure By Multinational Corportion. Universitas Ottawa. 
Thoyibatun, S. (2009). Faktor-faktor Yang Berpengaruh Terhadap Perilaku Tidak Etis Dan Kecenderungan Kecurangan Akuntansi Serta Akibatnya Terhadap Kinerja Organisasi. Ekuitas: Jurnal Ekonomi Dan Keuangan, 16(2), 245-260.

Timofeev, Y. (2017). Essays On Occupational Fraud. Frankfurt am Main.

Tuanakotta, T. M. (2017). Akuntansi Forensik dan Audit Investigatif (Edisi 2). Jakarta, Indonesia: Salemba Empat.

Vona, B. L. W. (2008). Organizational Fraud Risk Assessment.

Welton, R. E., Lagrone, R. M., \& Davis, J. R. (1994). Promoting The Moral Development of
Accounting Graduate Students: an Instructional Design And Asssessment. Accounting Education: An International Journal, 3(1), 35-50. https://doi.org/10.1080/0963928940000 0004

Wilopo. (2006). Analisis Faktor-faktor Yang Berpengaruh Terhadap Kecenderungan Kecurangan Akuntansi:Studi Pada Perusahaan Publik dan Badan Usaha Milik Negara Di Indonesia. Simposium Nasional Akuntansi 9, 21-69.

Wolfe, D. T., \& Hermanson, D. R. (2004). The Fraud Diamond: Considering the Four Elements of Fraud. CPA Journal, 74(12), 38-42. 